\title{
Ethical Leadership Impact on the Turnover of Islamic Banks in Kuwait
}

\author{
Mohammad A. O. J. Almutairi ${ }^{1}$, Abdullah A. O. J. Almutairi ${ }^{1}$, Ali S. S. Almarri ${ }^{2} \&$ Bader Ali KH M. Almutairi ${ }^{2}$ \\ ${ }^{1}$ Master of Business Administration, AL-albayt University, Jordan \\ ${ }^{2}$ Master of Business Administration, Delmon University for Science and Technology, Bahrain \\ Correspondence: Mohammad A. O. J. Almutairi, Master of Business Administration, AL-albayt University, \\ Jordan. E-mail: ajmiii@live.com
}

Received: September 23, 2019

Accepted: November 20, 2019 Online Published: December 12, 2019

doi:10.5539/ijbm.v15n1p77

URL: https://doi.org/10.5539/ijbm.v15n1p77

\begin{abstract}
This study aimed at identifying the impact of ethical leadership on work turnover in Islamic banks in Kuwait. The study population consisted of 5685 administrators working in Islamic banks in Kuwait. A random stratified sample amounting 360 administrators was selected for the purpose of questionnaire distribution. 302 questionnaires were recollected valid for analysis representing $83.9 \%$ of the total sample.

The researcher concluded several results, most notably that there is a statistically significant impact at $(\alpha \leq 0.05)$ level of ethical leadership with its dimensions (personal traits, behaviors and human relations, administrative qualities and decision-taking) in work turnover in Kuwaiti Islamic banks.

The recommendations focused on paying attention of Islamic banks managers of in Kuwait practicing ethical leadership in all fields, and studied have to provide appropriate organizational climate to maintain the continuity of competent staff in the bank and adopting training programs for Islamic banks managers that contribute in developing knowledge levels for ethical leadership practicing requirements and its role in reducing the work turnover.
\end{abstract}

Keywords: Ethical leadership, Personality traits, Behaviors, Human relationships, administrative qualities, and decision-taking, work turnover, Islamic banks in Kuwait

\section{Introduction}

Understanding ethical leadership and its impact on organizations performance of is also important issue because leadership is an important motivation to improve organization's performance. The primary purpose of any organization is to survive and maintain its entity through improving its performance and enhancing its competitiveness in targeted markets.

On the other hand, effective leadership has an important role for stakeholders and their institutions to produce best services through effective use of existing resources. Ethical leadership has significant benefits for all organizations, as they contribute - as several studies have indicated - to reduce employee absenteeism, misconduct, improved job satisfaction and performance, and managers who are ethical leaders are often considered as more proper to promotion opportunities. Thus, this is an important pillar of successful organizational processes.

Work turnover is also one of the major challenges facing organizations today, where employees are identified as very important organizational assets. Since high costs are beard when qualified employees quite their jobs and recruiting alternative employees and train the same. Staff turnover is therefore an important threat to organizations that must be best faced

Islamic banks in Kuwait are characterized with distinguished financial performance, and turning on from different society classes, which in its turn contributed into its surpassing the commercial banks, which drives commercial banks to open Islamic windows to retain the current customers and attracting new customers.

Ethical leadership practices are part the Islamic principles that must be adhered to in business organizations, which contributed to its importance emergence in Kuwaiti Islamic banks that implement Islamic Sharia in all of their transactions with the existence of an organizational culture that govern Islamic business in the bank.

This study aims to highlight the importance of ethical leadership in Kuwaiti Islamic banks and measure impact of 
its application on work turnover.

\subsection{Significance of Study}

Ethical leadership has a great importance in Islamic banks as it complies with the Islamic Shari'a guidelines. The study theoretical importance emerges from its handling with an important topic in Islamic banks, namely ethical leadership, as this study is deemed as one of the new studies according to researcher's best knowledge, which handles the impact of ethical leadership on work turnover in Islamic banks in Kuwait. This study will contribute to enrichment of the scientific library in new studies in this subject, which is considered one of important topics in the State of Kuwait.

While the practical importance emerges using this study in making important recommendations that contribute in reducing the desire to leave the work in Islamic banks in Kuwait and enhancing the use of ethical leadership in achieving that.

\subsection{Problem Statement}

The economic environment in Kuwait has been affected by the aftermath of the global financial crisis, which has negatively affected various economic sectors. The Islamic banking sector in Kuwait is also affected by this crisis as the rest of economic sectors, which contributed in increasing work turnover rates, whether voluntary or compulsory. Through the nature of researcher work and his relationship with several Islamic banks in the State of Kuwait, he found that there is an increasing problem in work turnover rates in these banks, which requires stopping at their causes, which may be due to some of leadership methods used. So the research problem is to answer the following questions:

1. What is the level of ethical leadership application in Islamic banks in Kuwait?

2. What is the level of work turnover in Islamic banks in Kuwait?

3. What is the impact of ethical leadership on work turnover in Islamic banks in Kuwait?

\subsection{Research Hypothesis}

In light of the study problem and the questions the following main hypotheses were formulated:

1.3.1 The main Hypothesis

H0: There is no statistically significant impact at $(\alpha \leq 0.05)$ level of ethical leadership with its dimensions collectively (personal traits, behaviors, human relations, administrative qualities and decision-taking) on work turnover in Kuwaiti Islamic banks.

The following sub-hypotheses were derived:

H01: There is no statistically significant impact at $(\alpha \leq 0.05)$ level of ethical personal traits, on work turnover in Kuwaiti Islamic banks

H02: There is no statistically significant impact at $(\alpha \leq 0.05)$ level of behaviors and human relations, on work turnover in Kuwaiti Islamic banks

H03: There is no statistically significant impact at $(\alpha \leq 0.05)$ level of administrative qualities and decision-taking on work turnover in Kuwaiti Islamic banks

\subsection{Research Model}

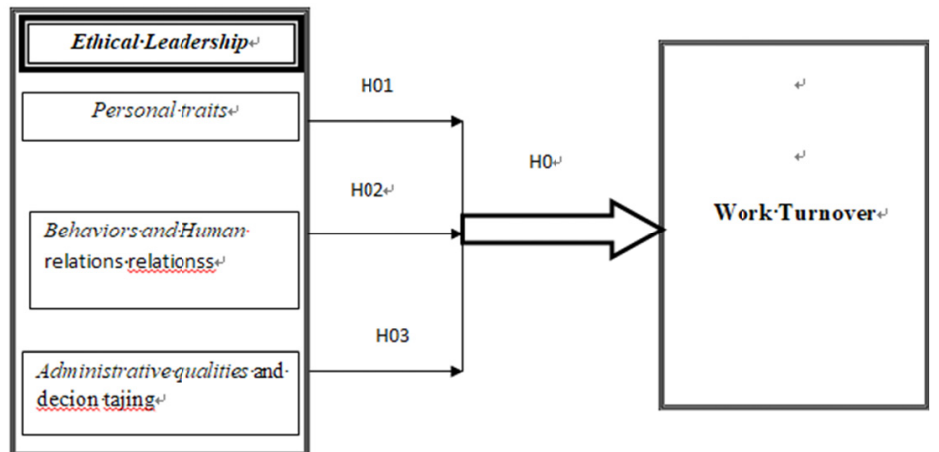

Source: Prepared by researcher according to the following sources: (Daradkeh and Al-Mutairi, 2017), (Conrad, 2013), (House, 2006), (Abdali, 2011), (Arokiasamy, 2013) and (Salem, 2009). 


\section{Literature Review}

\subsection{Ethical Leadership}

Ethical leadership concept emerged as one of the factors affecting many aspects of organization. Many scholars have discussed ethics and its application in organization. Many scholars have studied ethical leadership concept, for example Shaniqua, Kalyar, and Ahmad (2018) attempted to study the relationship between ethical leadership and job satisfaction as influences performance. They explained that ethical leadership positively affects job satisfaction, making employees more satisfied with their jobs and better able to deliver better performance with lower turnover levels. . When employees feel that their leaders treat them equaly, trust and honesty, they are more likely to be satisfied with their jobs and more open to solve problems that may arise as well as delivering better performance that affects organization as a whole.

By understanding the idea of job ethics, a set of ethical principles can be formed and communicated to employees for their commitment (Jalil, Azam, \& Rahman, 2010). In addition, an organization needs to consider the impact of ethical rules on the long-term ease of organization management, by arranging of key systems that can be used to activates ethical standards in business activities (Schnebel \& Bienert, 2004). On the other hand, weak ethical principles can lead managers in organizations to make misleading and erroneous choices that affect their activities in the future, especially in the case of damage to the funds of individuals or other organizations. (Enofe, Ogbeide, \& Julius, 2015).

Yates (2014) also indicated that with a good level of leadership style based on influential positive ethics, there will be space between employees to deal positively with their leaders, which in turn can positively impact their job satisfaction and increase their organizational commitment and thus reduce work turnover . Ethical leadership practices directly affect employee satisfaction, organizational loyalty, the importance of work, inspiration, and team spirit and thus on job performance. It should be noted that the idea of leadership is not only to follow a particular leadership style capable of presenting the organizational mission and achieving the vision; it is also a way to deal with employees and convince them that their leadership wants the best for them based on the ethical rules that are followed (Xu, Zhong, \& Wang, 2013, 676).

Ethical leadership was defined by Okan and Akyüz (2015) as "the process of controlling the behavior of leaders and behaviors in a manner that is morally acceptable and leads to employee satisfaction." On the other hand, Eisenbeiss and Knippenberg (2015) found that moral leadership "is to provide an appropriate stream of thinking and behavior to individuals and to promote such behaviors they have".

Williams and Seaman (2016) also define ethical leadership as "the process of influencing individuals through ethical values, virtues, and principles. Ethical leadership is a description of ethical relation which gathers between leader and organization subordinates which are developing from different aspects including ethics principles, context principle, components principle, skills principle, outcome principle .

Ethical leadership is defined as "demonstrating appropriate behavior from the standard aspect through personal actions and personal relationships, and enhancing employees' behavior through two-way communication, reinforcement, and decision-making" (Brown, Treviño, \& Harrison, 2005, p. 120).

House (2006, p. 339) indicated that ethical leadership is using power to help followers in handling conflicting values that emerge in work environment, in a way that contributes to their ethics".

Conrad (2013) explained that managers are perceived as ethical managers' relatively less than ethical persons, and employees accountability for their actions is the least evaluated aspect of ethical manager.

Ethical leadership includes the following dimensions that will be used in this study:

1. Personal traits.

2. Behaviors and human relations.

3. Administrative qualities and decision-taking. (Daradaka \& Al-Mutairi, 2017) and Conrad, 201

\subsection{Work Turnover}

One of the major challenges facing business organizations is high turnover of employees (Walsh, \& Taylor, 2007)

There are some factors that affect work turnover rates include: special recruitment and selection procedures, training and development opportunities; management methods, organizational commitement; labor shortage, stress and fatigue, seasonal nature of the industry, job dissatisfaction and staff treatment by their managers (Honyenuga \& AdzoyI, 2012). Work turnover can be defined as "behavior that describes the process of leaving or replacing staff in organization". (Abdali, 2011). 
Work turnover can also be defined as "termination of employee's organizational career path, which consists of a series of changes in the job from starting to quitting" (Arokiasamy, 2013).

Work turnover phenomenon is one of the most important phenomena associated with many indicators of organizational work, which refers to status stopping of individuals belonging to certain organizations, in particular those who receive financial returns from such organizations for their affiliation (Al-Salem, 2009, 209).

Some of its most significant indicators are:

- Inability to recruit the right people to work in the organization.

- Inability to solve the problem of work turnover.

- Low staff morale.

- Low level of employee satisfaction.

- Organization inability in diagnose the reasons for staff quitting their work.

- Poor attention to staff training

There are several reasons leading to work turnover that can be divided into two categories:

1- Reasons that can be avoided.

2- Inevitable reasons.

Avoidable causes: These include:

a. Dissatisfaction with wages.

B. Dissatisfaction with working environment: The plant may be poorly lit and dangerous

C. Job dissatisfaction: job can be very difficult. A routine task can be very tiring involving undue or dangerous stress.

D. Dissatisfaction with employee policies: Authoritarian management and limited promotional policies may prevail

Unavoidable causes: These include:

- Improving staff - take advantage of attractive opportunities.

- Familiarly circumstances.

- Climatic conditions.

- Societal Conditions: Racial Discrimination.

- Physical causes: ill health.

- Marriage.

- Retirement and death.

- Migration nature.

- Dismiss or dump

- Frequency: This may be due to seasonal trade, lack of material, lack of planning, lack of courage and insight to management (Ishmael,, Osamor \& Abraham, 2012).

Dimensions of work turnover can be summarized as follows:

1. Voluntary Turnover: means the voluntary staff quitting to Organization

2. Involuntary Turnover: means an involuntary turnover or discharge that "reflects employer's decision to terminate employment relationship."

1- Unavoidable turnover: inevitable turnover is caused by life decisions that go beyond the employer's control, such as the decision to move to a new area.

3. Avoidable work Turnover: is something that organizations can prevent by hiring, evaluating and motivating their employees more effectively. (Abdali, 2011 Arokiasamy, 2013;)

\section{Methodology}

The current research study follows quantitative approach as study method. It is an inductive approach that seeks to answer questions and generalize them to society. The study also follows the analytical approach in order to analyze 
the data collected through the questionnaire to achieve the main objective of the study: the impact of ethical leadership on work turnover in Islamic banks in Kuwait.

\subsection{Study Population and Sample}

The study population consisted of 5685 administrators working in Kuwaiti Islamic banks (http://www.kibs.edu.kw/bayanati). A random stratified sample 360 administrators (Sekaran, 2006) were taken to distribute the study questionnaire. 302 valid questionnaires representing $83.9 \%$ of the study sample were recollected.

\subsection{Data Collection Methods}

This study used two types of data collection sources:

\section{- Primary data sources:}

The data collected to form the current research base are preliminary data indicating the study sample responses to questionnaire statements. The questionnaire was designed as a source of primary data collection.

\section{- Secondary data sources:}

It relates to books, previous studies, scientific references and websites related to study topic.

\subsection{Statistical Processors}

To achieve the purposes of the study, SPSSv21 program was adopted and the following statistical methods were used:

1-Descriptive Statistic scales: To calculate means, standard deviations, frequencies and percent for questionnaire statements.

2-Cronbach Apha test for reliability Test.

3-Multiple regression analysis to test study hypotheses.

\subsection{Sample Characteristics Description}

This section includes a description of study sample demographic characteristics. To describe the study sample characteristics, frequencies and percents were calculated as follows:

1- Gender

Table 1. Sample distribution according to gender

\begin{tabular}{lll}
\hline Options & Frequency & Percent \\
\hline Male & 235 & 77.8 \\
Female & 67 & 22.2 \\
Total & 203 & 100.0 \\
\hline
\end{tabular}

It is clear from table 1 that males forms sample majority that is $(77.8 \%)$, while females form $(22.2 \%)$ of the total sample. This indicates that high percent is males which can be attributed to banks work nature under study.

2-Age

Table 2. Sample Distribution according to age

\begin{tabular}{lll}
\hline options & Frequency & Percent \\
\hline Less than 25 years & 31 & 10.3 \\
to less than 35 years25 & 74 & 24.5 \\
to less than 45 years35 & 92 & 30.5 \\
45 years + & 105 & 34.8 \\
Total & 302 & 100.0 \\
\hline
\end{tabular}

Table 2 indicates that $10.3 \%$ of study sample is less than 25 years, while $24.5 \%$ of the sample age ranged between 25 - to less than 35 years, $30.5 \%$ of the sample age ranged between 35 - to less than 45 years and the rest $34.8 \%$ of the sample their age is 45 years or more, such results matches with banks were requirement. 


\section{Qualification}

Table 3. Sample Distribution Members according to Educational Qualification

\begin{tabular}{lll}
\hline options & Frequency & Percent \\
\hline BSC & 242 & 80.1 \\
MSC & 40 & 13.2 \\
PhD & 20 & 6.6 \\
Total & 302 & 100.0 \\
\hline
\end{tabular}

With respect to sample qualification 80.1 of the total sample has BSC while 13.2 has MSC and finally 6.6 of the total sample has $\mathrm{PhD}$. The results indicate that banks are keen to employ university graduates to perform their work.

4-Experience years

Table 4. Sample distribution according to number of experience years

\begin{tabular}{lll}
\hline Category & Frequency & Percent \\
\hline Less than 5 years & 17 & 5.6 \\
5 to less than 10 years & 25 & 8.3 \\
10 to less than 15 years & 145 & 48.0 \\
15 years and over & 115 & 38.1 \\
Total & 302 & 100.0 \\
\hline
\end{tabular}

As for experience 5.6 of the total sample has an experience less than 5 years, 8.3 of the sample has ( 5 to less than 10 years), (48\%) of the sample has an experience ranges between (10 to less than 15 years). (38.1\%), of the total sample has an experience 15 years or more.

\subsection{Validity and Reliability of the Study Tool}

The faced validity of the instrument was verified by a number of specialized referees, where their comments were taken in consideration. In order to ensure that the coefficient represents the statement quality, the internal coefficient and its consistent of Cronbach's Alpha (Cronbach's Alpha) has been calculated with an alpha value of 0.921 which is acceptable because it is higher than the acceptable value 0.60. (Sekaran, 2006)

\subsection{Descriptive Statistics Results}

Means and standard deviations were calculated to describe the sample responses regarding study variables.

Table 5. Means, standard deviations and relative importance of study variables

\begin{tabular}{lllll}
\hline Variable number & & Mean & Standard deviation & Relative importance \\
\hline 1 & Personal features & 4.07 & .742 & High \\
2 & $\begin{array}{l}\text { Human Behavior and } \\
\text { Relationships }\end{array}$ & 3.88 & .876 & High \\
& $\begin{array}{l}\text { Administrative quality } \\
\text { and decision making }\end{array}$ & 3.78 & .762 & High \\
& & 3.92 & & High \\
Ethical Leadership & & 3.89 & .682 & High \\
Work turnover & & & .714 & \\
\hline
\end{tabular}

Table 5 indicated ethical leadership high importance, with a mean (3.92) and standard deviation (0.672). the table also indicates that (personal traits) dimension ranked. The first with a mean (4.07), and high relative importance, while (Administrative qualities and decision-making) dimension ranked last with a mean (3.78), with high relative importance. This indicates the banks interest in applying ethical leadership dimensions, in the same time the table indicates that turnover high level with a mean 3.89 . 


\subsection{Hypotheses Testing}

The main hypothesis:

H0: There is no statistically significant impact at $(\alpha \leq 0.05)$ level of ethical leadership with its dimensions collectively (personal characteristics, behaviors and human relations, administrative qualities and decision-making) in turnover of work in Kuwaiti Islamic banks.

The main hypothesis was subjected to multiple linear regression analysis. The results were as follows:

Table 6. Main hypothesis test results

\begin{tabular}{|c|c|c|c|c|c|c|c|}
\hline \multicolumn{8}{|c|}{ Model Summary } \\
\hline Model & $\mathbf{R}$ & R Square & \multicolumn{2}{|c|}{ Adjusted R Square } & \multicolumn{3}{|c|}{ Std. Error of the Estimate } \\
\hline 1 & .732 & .535 & .53 & & .48905 & & \\
\hline \multicolumn{8}{|c|}{ ANOVA } \\
\hline Model & & Sum of & ares & Df & Mean Square & $\mathbf{F}$ & Sig. \\
\hline \multirow{3}{*}{1} & Regression & 82.040 & & 3 & 27.347 & 114.342 & .000 \\
\hline & Residual & 71.272 & & 298 & .239 & & \\
\hline & Total & 153.312 & & 301 & & & \\
\hline
\end{tabular}

\section{Coefficients}

\begin{tabular}{|c|c|c|c|c|c|c|}
\hline Model & proportions & $\begin{array}{l}\text { Unstandardized } \\
\text { Coefficients } \\
\text { B }\end{array}$ & $\begin{array}{l}\text { Standardized } \\
\text { Coefficients } \\
\text { Std. Error } \\
\end{array}$ & Beta & $\mathbf{t}$ & Sig. \\
\hline \multirow[t]{4}{*}{1} & Personal features & .258 & .052 & .268 & 4.949 & .000 \\
\hline & $\begin{array}{l}\text { Human Behavior } \\
\text { and Relationships }\end{array}$ & .165 & .047 & .202 & 3.491 & .001 \\
\hline & Administrative & & & & & \\
\hline & $\begin{array}{l}\text { qualities and } \\
\text { decision making }\end{array}$ & .365 & .046 & .389 & 7.846 & .000 \\
\hline
\end{tabular}

Table 5 indicates that the correlation coefficient $(\mathrm{R}=0.732)$ indicates the relationship between independent and dependent variable. The impact of independent variables on dependent variable is statistically significant, since the calculated $\mathrm{F}$ value is (114.342).with a significant level $(\mathrm{Sig}=0.000)$ which is less than 0.05 . The value of coefficient determination $(\mathrm{r} 2=0.535)$, which indicates that $(53.5 \%)$ of the variation in (turnover) can be explained by the variation in (dimensions of moral leadership) collectively. therefore, is a statistically significant impact at $(\alpha \leq 0.05)$ level of ethical leadership with its collectively dimensions (personal characteristics, behaviors and human relations, administrative qualities and decision-making) in the turnover in the Kuwaiti Islamic banks.

The table of coefficients showed that:

-The value of (B) for(personal traits) dimension is (0.258) and the ( $\mathrm{t}$ ) value is (4.949), and significance value is $(\mathrm{Sig}=0.000)$, which indicates that impact of this dimension is significant, and therefore that there is a statistically significant impact at $(\alpha \leq 0.05)$ level for personal traits in the turnover in Islamic banks in Kuwait

-The value of (B) for(behaviors and human relations) dimension is $(0.165)$ and the $(t)$ value is $(3.491)$, and significance value is $(\mathrm{Sig}=0.000)$, which indicates that impact of this dimension is significant, and therefore that there is a statistically significant impact at $(\alpha \leq 0.05)$ level for behaviors and human relations in work turnover in Islamic banks in Kuwait

-The value of (B) for(administrative attributes and decision-making dimension is $(0.365)$ and the $(t)$ value is (7.846), and significance value is ( $\mathrm{Sig}=0.000)$, which indicates that impact of this dimension is significant, and therefore that there is a statistically significant impact at $(\alpha \leq 0.05)$ level for administrative attributes and decision-making in work turnover in Islamic banks in Kuwait 


\section{Results}

This study aimed to identify the impact of ethical leadership on work turnover work in Kuwaiti Islamic banks. The study population consisted of administrators working in Islamic banks in Kuwait. A random stratified sample amounting 360 administrators was taken to distribute the study questionnaire, and there results were concluded:

1. It was found that (personality traits) dimension ranked the first, with high relative importance, while (administrative qualities and decision-taking) ranked the second with high relative importance. This reflects banks interest in applying ethical leadership dimensions

2. There is a statistically significant impact of ethical leadership with its dimensions collectively (personal traits behaviors and human relations, administrative qualities and decision-taking) in work turnover of work in Kuwaiti Islamic banks. This enhances the importance of using ethical principles and rules that govern the of Islamic banks in Kuwait work upon dealing with employees

3. There is a statistically significant impact of personal traits in work turnover in Islamic banks in Kuwait, and this confirms the role of ethical aspects that govern leader personality in treating with employees and their importance in reducing work turnover in the bank.

4. There is a statistically significant impact of behaviors and human relations in work turnover in Islamic banks in Kuwait, and this enhances the importance of practices the ethical leader follows in treating employees and his colleagues.

5. There is a statistically significant impact of the administrative qualities and decision-taking in work turnover in Kuwaiti Islamic banks. This highlights the importance of qualities that ethical leader enjoys which contributes in administrative decisions taking that govern the work in Islamic banks in Kuwait.

\section{Recommendations}

The researcher recommends the following:

1- Managers of Islamic banks in Kuwait are requested to practice ethical leadership in all its fields, due to its importance in reducing work turnover.

1- Islamic banks have to provide appropriate organizational climate to maintain the continuity of competent staff in the bank

3-Adopting training programs for Islamic banks managers, which contribute to the development of knowledge levels of the requirements of practicing ethical leadership, and its role in reducing work turnover.

4-Holding training courses, seminars and workshops to aware managers of Islamic banks with the importance of ethical leadership and its role in reducing work turnover.

5-To carry out further studies on ethical leadership and its practicing level in other sectors such as commercial banks and insurance companies in the State of Kuwait

6-To carry out further studies on ethical leadership and its relationship to other variables such as organizational citizenship behaviors

\section{References}

Abdali, F. (2011). Impact of Employee Turnover on Sustainable Growth of organization in Computer Graphics Sector of Karachi, Pakistan. Afro Asian Journal of Social Sciences, 2(24), 1-27. https://doi.org/10.2139/ssrn.1907372

Al-Salem, M. (2009). Human Resources Management: An Integrated Strategic Approach. Jordan, Amman: Ithraa Publishing \& Distribution.

Arokiasamy, A.(2013). A Qualitative Study on Causes and Effects of Employee Turnover in the Private Sector in Malaysia. Middle-East Journal of Scientific Research, 16(11), 1532-1541

Brown, M. E., Treviño, L. K., \& Harrison, D. A. (2005). Ethical leadership: A social learning perspective for construct development and testing. Organizational Behavior and Human Decision Processes, 97, 117-134. https://doi.org/10.1016/j.obhdp.2005.03.002

Conrad, A. M. (2013). Ethical leadership in Kazakhstan: An exploratory study. The Journal of Values-Based Leadership, 6(1), 1-11.

Daradkeh, A., \& Al-mutairi, H. (2017). The Role of Ethical Leadership in Promoting Organizational Confidence 
among Primary School Principals from Taif Teachers' Perspective. The Jordanian Journal of Educational Sciences, 13(2), 223-237.

Eisenbeiss, S. A., Van Knippenberg, D., \& Fahrbach, C. M. (2015). Doing well by doing good? Analyzing the relationship between CEO ethical leadership and firm performance. Journal of Business Ethics, 128(3), 635-651. https://doi.org/10.1007/s10551-014-2124-9

Enofe, A. O., Ogbeide, O. L., \& Julius, O. M. (2015). Business Ethics and Corporate Growth. Business Ethics, $7(15), 139-148$.

Honyenuga, B., \& AdzoyI, P. (2012). The Influence of Retention Strategies on Labour Turnover in the Hospitality Industry in Ghana. International Journal of Multidisciplinary Research, 2(3), 27-37.

House, B. N. (2006). Administrative Leadership: Theory and Practice. Translation of Mayouf, Mohammed Moaz, Saudi Arabia, Riyadh: Institute of Public Administration

Ishmael, O., Osamor, P. I., \& Abraham, O. (2012). Labor Turnover: A Monstrous Development in a Mono-Cultural Capitalist Economy. Australian Journal of Business and Management Research, 2(2), 39-47.

Jalil, M. A., Azam, F., \& Rahman, M. K. (2010). Implementation mechanism of ethics in business organizations. International Business Research, 3(4), 145-155. https://doi.org/10.5539/ibr.v3n4p145

Okan, T., \& Akyüz, A. M. (2015). Exploring the Relationship between Ethical Leadership and Job Satisfaction with the Mediating Role of the Level of Loyalty to Supervisor. Business and Economics Research Journal, 6(4), 155-177.

Schnebel, E., \& Bienert, M. A. (2004). Implementing ethics in business organizations. Journal of Business Ethics, 53(1-2), 203-211. https://doi.org/10.1023/B:BUSI.0000039409.58757.a8

Sekaran, U. (2006). Research methods for business: A skill building approach. John Wiley \& Sons.

Shafique, I. N., Kalyar, M., \& Ahmad, B. (2018). The Nexus of Ethical Leadership, Job Performance, and Turnover Intention: The Mediating Role of Job Satisfaction. Interdisciplinary Description of Complex Systems: INDECS, 16(1), 71-87. https://doi.org/10.7906/indecs.16.1.5

Walsh, K., \& Taylor, M. S. (2007) Developing in-house careers and retaining management talent: what hospitality professionals want from their jobs, Cornell Hotel. Restaurant and Administrative Quarterly, 48(2), 163-210. https://doi.org/10.1177/0010880407300521

Williams, J. J., \& Seaman, A. E. (2016). The influence of ethical leadership on managerial performance: Mediating effects of mindfulness and corporate social responsibility. Journal of Applied Business Research, 32(3), 815-828. https://doi.org/10.19030/jabr.v32i3.9659

Xu, X. D., Zhong, J. A., \& Wang, X. Y. (2013). The impact of substitutes for leadership on job satisfaction and performance. Social Behavior and Personality: An International Journal, 41(4), 675-685. https://doi.org/10.2224/sbp.2013.41.4.675

Yates, L. A. (2014) .Exploring the Relationship of Ethical Leadership with Job Satisfaction, Organizational Commitment, and Organizational Citizenship Behaviour. The Journal of Values-Based Leadership, 7(1), $1-15$.

\section{Copyrights}

Copyright for this article is retained by the author(s), with first publication rights granted to the journal.

This is an open-access article distributed under the terms and conditions of the Creative Commons Attribution license (http://creativecommons.org/licenses/by/4.0/). 